\title{
Why Invest in Strategic Communication? Because It Creates Value
}

Original scientific paper _ UDK 316.776:659.44 _ Received on 02 May 2016

\section{Dejan Verčič}

Professor and Head of Center for Marketing and Public Relations, Faculty of Social Sciences, University of Ljubljana, Slovenia. Email: dejan.vercic@fdv.uni-lj.si

\section{Abstract}

Strategic communication creates value by co-creating the future. The pre-modern society was about the past, the modern about the present, and the post-modern is about the future. Globalization, digitalization and dematerialization are changing the world around us beyond recognition. Emerging market and developing economies have overtaken advanced economies with unimaginable consequences for our, Western way of life: the welfare state is dying. Digitalization is reconfiguring demarcations between public and private domains, political and commercial communication. Our understanding and regulation of rights and responsibilities regarding privacy and freedoms are outdated. Dematerialization is reconfiguring value creation and wealth is migrating from material into immaterial assets. Human, organizational and relational capital are co-created in processes of strategic communication between organizations and stakeholders. This is reflected in increasing investments in strategic communication and transformations of all kinds of organizations into media organizations. We are witnessing the emergence of mediatization of everything.

Keywords: public relations, communication management, strategic communication 


\section{Introduction}

Strategic communication is the purposeful use of communication by an organization to fulfill its mission (Hallahan, Holtzhausen, Rulker, Verčič, Sriramesh, 2008). As a current management practice (Verčič, Grunig, 2000), it is an artefact of American culture (Sriramesh, Verčič, 2012), a part of the "the modern West" (Debeljak, 2012, p. 49). Yet, it is highly diverse not only between "the West and the rest" (see Sriramesh, Verčič, 2009), but also between the US and Europe (Ruler, Verčič, Bütschi, Flodin, 2004; Verčič, Ruler, Bütschi, Flodin, 2001), and even within Europe (Ruler, Verčič, 2004).

Strategic communication is gaining in importance because the contemporary society is, in the words of Anthony Giddens, "a society increasingly preoccupied with the future" and the future can be only imagined and communicated. The quoted sentence about "a society increasingly preoccupied with the future" continues and says that ours is "a society increasingly preoccupied with the future (and also with safety), which generates the notion of risk" (Giddens, Pierson, 1998, p. 209). Giddens, a Brit, developed his ideas on the modern as a risk society in discourse with a German sociologist, Ulrich Beck (1992).

Currently, three processes shape our perception of the future and are generating risks: globalization (not so much an integration of the globe as a shift of power from the West to the rest), digitalization (which is reconfiguring demarcations between public and private domains, political and commercial communication) and dematerialization (although this is happening in many domains of our life, here we focus on dematerialization of wealth into intellectual, which is essentially communication, capital). As a consequence, organizations are becoming self-aware, gaining reflexivity and subjectivity, transforming their inner and outer environments into mediate structures: we are witnessing, literally, the mediatization of everything: individuals, often physically proximate, communicating via social media on their tablets or mobile telephones, organizations expressing themselves in all kinds of internal and external media, from print magazines to websites, from pictures on Instagram to video on CCTV or on YouTube. Even governments are moving everything, from nation building to warfare, into media (while drone attacks are very direct for the targets, they are nearly indistinguishable from videogames for politicians, generals and operators). 


\section{Globalization}

Globalization is the process in which the world is becoming "a global village". The term was, if not invented, then at least popularized, by media theorist Marshal McLuhan (1964, p. 3) to denote that "the Western world is imploding... Today, after more than a century of electronic technology, we have extended our central nervous system itself in a global embrace, abolishing both space and time as far as our planet is concerned. Rapidly, we approach the final phase of the extension of man - the technological simulation of consciousness, when the creative process of knowing will be collectively and corporately extended to the whole of human society...”. The sensory integration of the world has extended beyond the borders of the West and has embraced "the rest" as well. But what is really generating risk to "the West" today is that it is losing, that it has lost its central position in the global economic system, and this will also have consequences for social and political orders.

The International Monetary Fund (IMF) estimates that, in the middle of the first decade of the $21^{\text {st }}$ century, the emerging markets and developing countries surpassed the advanced economies, i.e., the advanced economies (which are named so because they are supposed to be wealthier than "the rest") are now poorer than emerging market and developing economies. Figure 1 shows how the balance of power has changed in the past 35 years:

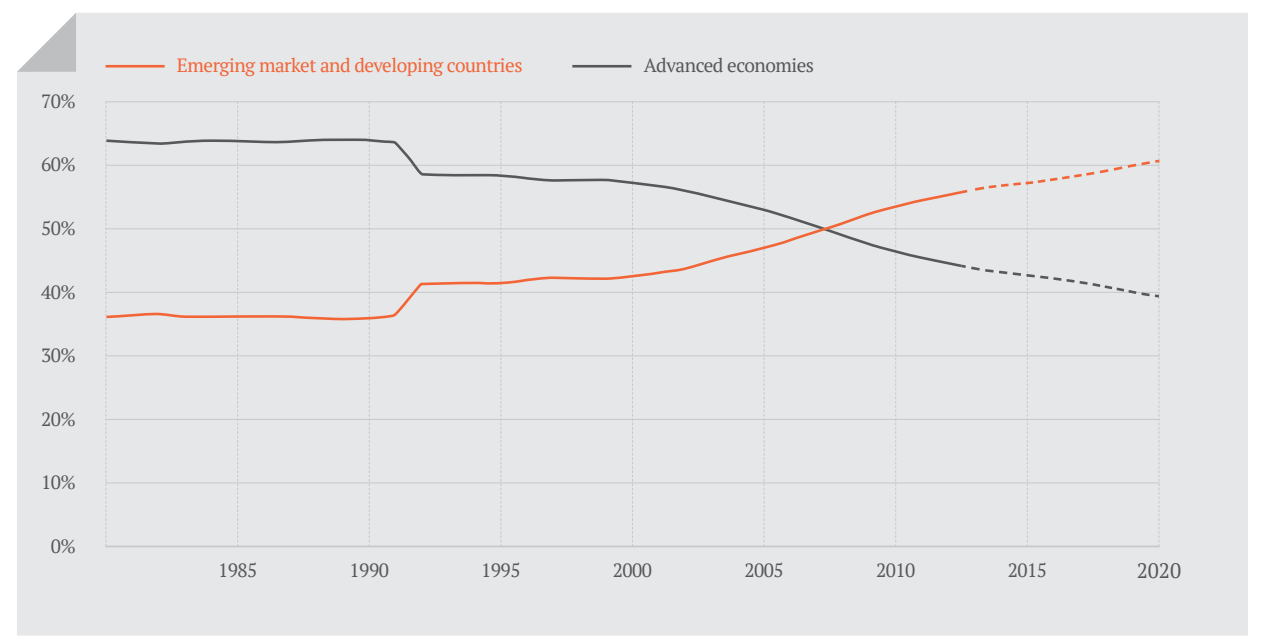

Figure 1: The West and the rest: GDP based PPP share of world total\%

Source: International Monetary Fund, World Economic Outlook in Google Public Data Explorer (April 11, 2016) 
The reversal of the relative shares of the world's GDP between "the West and the rest" has direct consequences on the way of life as we know it, in particularly, in Europe. We, in "the West", are simply not rich enough anymore to sustain the way of life as we knew it in the second half of the $20^{\text {th }}$ century (after the Second World War). The problem is that only few are prepared to see, and even fewer to publicly admit it. The Dutch are known for being extremely direct in their communication, and it was their King Willem-Alexander who declared it in a statement of his government that the welfare state is dead (AP, 2013). There are many reasons for the current lousy state of the European Union: a nearly decadelong financial and economic crisis, depopulation and aging, the Middle Eastern and North African wars fueling an immigration crisis...; but of all of them, losing global power, and with it, a corresponding way of life is the most fatal. The future of Europe (and the West) is uncertain and risky.

\section{Digitalization}

The Internet is changing everything. Digitalization may be the defining characteristic of the modern era (Castells, 2010). One of the most intriguing characteristics of digitalization is expressed in "the idea of 'convergence' across a number of different processes and domains of social life" (Brennen, Kreiss, 2014): infrastructural, terminal, functional and rhetorical, and market convergence. Infrastructural convergence describes how digitalization converges material infrastructures of communication: "a single physical means - be it wires, cables, or airwaves - may carry services that in the past were provided in separate ways" (Pool, 1983, p.23). Device or terminal convergence describes how digitalization enables the consolidation of multiple devices into one, as we all experience it in smart phones, which are mobile telephones, cameras, computers, audio and video recorders, calculators, notepads... And we may be at the edge of oblivion of the notion of the device itself: Google CEO Sundar Pichai announced that "the next big step will be for the very concept of the 'device' to fade away" and be replaced by "an intelligent assistant” (Guynn, 2016). Functional and rhetorical convergence describes not only consolidation of various devices into one, but also their services: while in the past there was a correspondence between a machine and a service it provided, now various services can be provided by various machines (PCs, laptops, handhelds, mobile 
telephones, videogame consoles, smart televisions...). And all these convergences further converge in market convergence, which describes convergence of once separate industry sectors (computing, information, media, telecommunications) in consolidated companies or company clusters (just consider what kind of companies are Apple, Amazon, Facebook, Google, Microsoft). There are two additional societal convergences which result from the aforementioned technological convergences: the first is domain convergence, between what we perceive and regulate as public and private domains of our life, and the second is systemic convergence, between what we perceive and regulate as political and commercial subsystems of our societal totality.

Nowhere is domain convergence, convergence of what is considered private and what public, more pertinent than in social media, Facebook, Twitter, Instagram... Words, photos, videos, linkages/networks on social media are making our lives as transparent as they were in the pre-modern era. In the old world, village communities knew everything about everybody, as they still do in rural areas today. Not only does everybody know who you are, and what and when you are doing, but also who were your ancestors, who are your relatives; you are always situated in a continuous real-life "Big Brother". In this context, it can be said that the TV Big Brother is nothing but an urban satire of pre-urban life in which people constantly observed each other. And presence in social media is a simulacrum of "the global village" in which urban individuals voluntarily open their living rooms and bedrooms to everybody else: again we know everything about everybody else in real time, with unimaginable consequences. Potential and current employers check their potential and current employees' private lives - and practically nobody objects. It has become a commonly accepted practice that our homes are no longer our castles, everybody is invited to peek. In this new brave world of glass walls, who needs intelligence services anyway? Assange and Snowden are but two surnames soon to be forgotten.

Social media did not affect only the line between what is private and what is public, but also the line differentiating between what is considered political and what commercial, causing systemic convergence. Many of our, Western freedoms are founded on that difference. It is the freedom of political speech that is protected in modern democracies, not freedom of commercial speech. Freedom of discussing and criticizing public policies and politicians enables democracies to operate, while at the same time limiting freedom of commercial 
communication to influence vulnerable or sell dangerous products or services. There is a real difference between selling cigarettes or politicians, and once we lose this difference everything becomes tradable and politicized at the same time. Modern society was based on the differentiation of its subsystems: political, social, scientific, religious... Once we merge all of them into one amalgam again, there is no basis left to discuss different rules that regulate different subsystems and the differences and tensions between them that give us space for at least partial and temporary autonomy and self-determination.

Domain and systemic convergences are walking hand in hand; they are two sides of the same coin for which we are selling our Western way of being, our way of life. Consider what is left of "the mass media". In the West, the mass media were internally differentiated and regulated by two different sets of rules. One set of rules applied to the editorial part of the mass media, occupied by journalists and editors, while another set of rules applied to the advertising part (Tkalac Verčič, Verčič, Laco, 2008). In the realm of strategic communication, two different industries were serving these two different parts of the mass media market: marketing and advertising agencies were focused on advertising sections of the mass media, while public relations and publicity agencies were focused on editorial content. There was some cross-fertilization (e.g. advertorials), but intrusion of commercial interests in editorial space was seen as illegitimate, as "hidden advertising". With the Internet, blogs and social media and corresponding convergences, editorial and advertising spaces also converged. Entering in the language of strategic communication were "branded journalism", "native advertising” and “content marketing” (Verčič, Tkalac Verčič, 2015; Zerfass, Verčič, Wiesenberg, 2016). Today it is becoming less and less possible and meaningful to differentiate between editorial and advertising not only in digital, on-line, but also in all other, off-line media. There is an obvious convergence of once different spaces into a single one.

\section{Dematerialization}

Dematerialization is, in general, a fundamental enabler of sustainable development for the future: human depletion of the Earth's natural resources is unsustainable and if we are to survive we have to produce more with less. Nowhere is this more obvious than in the production of the mass media: while analogue media required investment of physical 
resources (e.g. massive cutting of trees to produce paper), digital media demand no "material" investment: all you need is one device (a PC, laptop, tablet, mobile telephone...) and with it you can produce as many media as you like. Not only that: wealth itself is dematerializing and becoming more and more virtual. In the past, you needed land, buildings, machinery, gold, diamonds, something to show and touch to be rich. Today, all you need is others to believe that you will be able to deliver something valuable in the future. Today's wealth is not in the present, but in the future. Look at the Figure 2:

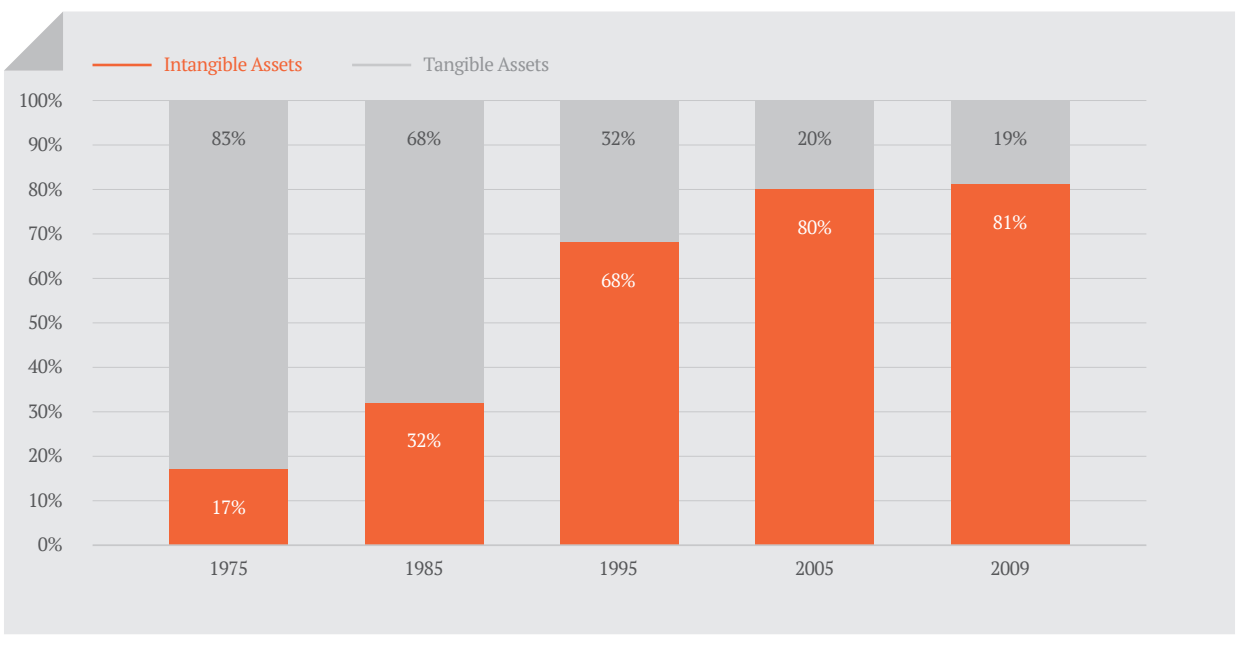

Figure 2: Components of S\&P 500 Market Value

Source: Ocean Tomo (http://www.oceantomo.com/2013/12/09/Intangible-Asset-Market-Value-Study-Release/, April 11, 2016)

Figure 2 shows how the stock market value of the top 500 companies listed on the two major New York stock exchanges (NYSE and NASDAQ) changed over the past thirty-five years. In 1975,83 percent of the market value was in physical assets. If you liquidated a company at that time, you could still get a lot for its parts: land, building, machinery were the major parts of its worth. In 2009, only 19 percent of the market value was left in physical assets and the remaining 81 percent in immaterial assets. These assets are hard to see or touch. They are literally produced in the process of communication. Their value is predominantly in the heads of people who believe in them, in their futures, and who are prepared to invest their money into something that is yet to happen. Increasing volatility of capital markets in the past fifty years is directly related to our whims, greed and fear. 


\section{Capital and communication}

The dematerialization of capital and its formation are entering the domain of communication and for this reason the importance of and investments in communication are rising. We have entered "intellectual capitalism" (Stewart, 1998, p. xviii). But intellectual capitalism is not based on some "objective" reality of information travelling around the Internet. On the contrary, "intellectual capital (...) is knowledge-based" and "knowledge is a personal, subjective process emerging from previous experiences and current events, while information is objective data about the environment" (Roos, Roos, Dragonetti, Edvinsson, 1997, p. 25).

There are various definitions and differentiations of intellectual capital. Here we follow the one proposed by Johan Ross et al. (1997, p. 34) that distinguishes between employees, internal structure and external structure: "intellectual capital is composed of (and generated by) a thinking part (human capital) and a non-thinking part (structural capital) structural capital has an internal and external component (organizational and relational capital respectively), while human capital comes from knowledge, the attitude and the intellectual agility of employees".

Today's capital is generated in communication with employees (human capital), between employees (organizational capital) and between employees and other stakeholders (relational capital). It is no wonder that German communicators and controllers (basically accountants who are responsible for establishing benchmarks or standards and comparing actual performance against them) collaborate to agree on Position Paper Communication Controlling about How to maximize and demonstrate the value creation through communication (DPRG/ICV, 2011): German multinational companies employ thousands of professionals spending hundreds of millions of Euros in communication, and they want to manage it as disciplined as any other resource. Linking communication and business strategy is the most important issue for European communicators in the past decade as measured by the European Communication Monitor, the largest annual study in strategic communication in the world (Verčič, Verhoeven, Zerfass, 2014). 


\subsection{Human Capital}

Strategic communication affects human capital formation and cultivation through internal communication (Tkalac Verčič, Verčič, Sriramesh, 2012), education (Ruler, Verčič, 2013) and reflexivity (Ruler, Verčič, 2005). Although it is impossible to imagine an organization without some sort of communication within it, i.e. internal communication, strategic internal communication gains in importance when production becomes dependent on creativity, innovation and knowledge. Generation of human capital is influenced by strategic internal communication, a purposeful use of communication by an organization to create and direct knowledge, attitudes and agility.

\subsection{Organizational capital}

Strategic communication affects organizational capital primarily by affecting organizational culture. Peter Drucker is credited for saying that culture eats strategy for breakfast. "Culture is created by the constant interaction of organizational members" (Roos et al., 1997, p. 50) and leaders influence it through strategic internal communication (Welch, Jackson, 2007). One of the largest studies in public relations and communication management, The Excellence Study (Dozier, Grunig, Grunig, 1995; Grunig, 1992; Grunig, Grunig, Dozier, 2002), found that strong organizational culture recursively also affects communication. Organizational culture is both an antecedent and a consequence of organizational (and leadership) behavior (Sriramesh, Verčič, 2012). As a consequence of both digitalization on one hand and of the importance of communication for the generation of organizational capital, organizations increasingly mediatize themselves, produce more and more media themselves, beyond what was traditionally considered as in-house media (magazines, newsletters...), and although not in the media business, they are increasingly becoming media organizations in parallel with their core businesses (Savič, 2016).

\subsection{Relational capital}

Strategic communication affects the formation and cultivation of relational capital through

"management of communication between an organization and its publics" (Grunig, Hunt, 
1984, p. 6), establishment and maintenance of "mutually beneficial relationships between an organization and the publics on whom its success or failure depends" (Cutlip, Center, Broom, 2000, p. 6), customers, suppliers, regulators, financiers, local communities, and other stakeholders. "CEOs have joined politicians and entrepreneurs in becoming public personae" (Zerfass et al., 2016, p. 39), and they have to learn how to navigate through often conflicting demands and expectations. Unique configurations of relationships with key stakeholders and of reputation(s) among them are nearly impossible to imitate as a source of competitive advantage (Fombrun, 1996; Key, 1995; Rindova, Williamson, Petkova, Sever, 2005; Vidaver-Cohen, 2007) and studies in strategic communication are recently focusing on relationship cultivation strategies to produce high-quality relationships of organizations with their stakeholders as the primary objectives (effects) of excellent public relations (Huang, 2007; Hung, 2007).

\section{Conclusion}

Globalization, digitalization and dematerialization are changing human lives beyond recognition. Changing are balances between "the West and the rest", between private and public domains, political and commercial communication, material and immaterial assets and capital. Today we are faced with future uncertainties and risks. The major tool to address these is communication.

The strategic use of communication affects how organizations generate and nurture human, organizational and relational capital. Corporate leaders understand that they and their organizations are observed and that they are becoming transparent, willingly or forcefully. This stimulates reflexivity and promotes listening (Zerfass, Tench, Verčič, Verhoeven, Moreno, 2014; Zerfass, Verčič, Verhoeven, Moreno, Tench, 2015). Reflexivity promotes mediatization, increasing production of media by non-core media organizations themselves, turning all kind of organizations into media(tized) organizations (Savič, 2016). This has had an accelerating effect on the growth of the strategic communication sector: while there were, at the beginning of the twentieth century, hardly any public relations or strategic communication practitioners (definitely not under these two names), in the middle of the twentieth century, in the USA, there were approximately one public relations / strategic communication practitioner to 
every journalist. In the first decade of the twenty-first century, in the USA, there are five strategic communicators to every journalist, and although the rest of the world is lagging behind, it is following the same trend: there are fewer journalists around and the number of strategic communicators is growing (Verčič, Tkalac Verčič, 2015).

There is a noticeable gap in the West between the USA and Europe: all five major global communication companies (Amazon, Apple, Facebook, Google and Microsoft) are based in the USA. Asia is rising with, e.g. Alibaba in China and Samsung in Korea. Europe has nothing similar and its future seems more uncertain and riskier. What Europe is lacking are more investments in strategic communication, because it creates value. Times are changing and the important question is: how much will they affect us and how much will we affect them?

\section{Reference List}

- AP (2013). Dutch King Willem-Alexander declares the end of the welfare state. Independent, 17 September. Retrieved from http://www.independent.co.uk/news/world/europe/dutch-king-willem-alexander-declares-the-end-of-the-welfarestate-8822421.html, 18 April 2016.

- Beck, U. (1992). Risk society: Towards a new modernity. London: Sage.

- Brenner, S., Kreiss, D. (2014). Digitalization and digitization. Culture digitally, 8 September. Retrieved from http://culturedigitally. org/2014/09/digitalization-and-digitization/, 1 May 2016.

- Castells, M. (2010). The rise of the network society. Malden, MA: Wiley-Blackwell.

- Cutlip, S. M., Center, A. H., Broom, G. M. (2000). Effective public relations, $8^{\text {th }}$ ed. Upper Saddle River, NJ: Prentice Hall.

- Debeljak, A. (2012). In praise of hybridity: Globalization and the modern Western paradigm. In: Sriramesh, K., Verčič, D. (Eds.), Culture and public relations: Links and Implications (pp. 42-53). New York, London: Routledge.

- Dozier, D. M., Grunig, L. A., Grunig, J. E. (1995). Manager's Guide to Excellence in Public Relations and Communication Management. Mahwah, NJ: Lawrence Erlbaum Associates.

- DPRG/ICV (2011). Position paper Communication Controlling - How to maximize and demonstrate the value creation through communication. Bonn, Gauting: Deutsche Public Relations Gesellschaft / Internationaler Controller-Verein.

- Fombrun, C. (1996). Reputation: Realizing Value from the Corporate Image. Boston, Massachusetts: Harvard Business School Press.

- Giddens, A., Pierson, C. (1998). Conversations with Anthony Giddens: Making sense of modernity. Stanford University Press.

- Grunig, J. E. (1992) (Ed.), Excellence in Public Relations and Communication management. Hillsdale, NJ: Lawrence Erlbaum Associates.

- Grunig, J. E., Hunt, T. (1984). Managing public relations. New York: Holt, Rinehart and Winstoon.

- Grunig, J. E., White, J. (1992). The effects of worldviews on public relations theory and practice. In: Grunig, J. E. (Eds.), Excellence in Public Relations and Communication management (pp. 31-64). Hillsdale, NJ: Lawrence Erlbaum Associates.

- Grunig, L. A., Grunig, J. E., Dozier, D. M. (2002). Excellent Public Relations and Effective Organizations: A Study of Communication Management in Three Countries. Mahwah, NJ: Lawrence Erlbaum Associates.

- Guynn, J. (2016). Google CEO: ‘Devices’ will be things of the past. USA Today, 29 April. Retrieved from http://www.usatoday. com/story/tech/news/2016/04/28/google-ceo-predicts-ai-fueled-future/83651232/, 1 May 2016.

- Hallahan, K., Holtzhausen, D., Ruler, B. van, Verčič, D., Sriramesh, K. (2008). Defining strategic communication. International journal of strategic communication, 1 (1), 3-35.

- Huang, Y. H. (2007). A revisit of symmetrical communication from an international perspective: Status, effect, and future 
research directions. In: Toth, E. L. (Ed.), The Future of Excellence in Public Relations and Communication Management: Challenges for the next generation (pp. 235-262). Mahwah, NJ, Lawrence Erlbaum Associates.

- Hung, C. F. (2007). Toward the theory of relationship management in public relations: How to cultivate quality relationships. In: Toth, E. L. (Ed.), The Future of Excellence in Public Relations and Communication Management: Challenges for the next generation (pp. 443-476). Mahwah, NJ, Lawrence Erlbaum Associates.

- Key, J. (1995). Foundations of Corporate Success: How Business Strategies Add Value. Oxford, UK: Oxford University Press.

- Pool, I. de S. (1983). Technologies of freedom. Cambridge, MA: Harvard University Press.

- Rindova, V. P., Williamson, I. O., Petkova, A. P., Sever, J. M. (2005). Being good or being known: An empirical examination of the dimensions, antecedents, and consequences of organizational reputation. Academy of Management Journal, 48, $1033-1049$.

- Roos, J., Roos, G., Dragonetti, N. C., Edvinsson, L. (1997). Intellectual capital: Navigating the new business landscape. London: Macmillan Press.

- Ruler, B. van, Verčič, D. (2004). Public relations and communication management in Europe: A nation-by-nation introduction to public relations theory and practice. Berlin and New York: de Gruyter.

- Ruler, B. van, Verčič, D. (2005). Reflexive communication management: Future ways for public relations research. In: Kalbfleisch, P. (Ed.), Communication yearbook 29 (pp. 239-272). New York: Routledge.

- Ruler, B. van, Verčič, D. (2013). Europe, Practice of public relations. In: Heath, B. (Ed.), Encyclopedia of public relations, Vol. II, 2nd ed. (pp. 308-312). Los Angeles, CA: Sage.

- Ruler, B. van, Verčič, D., Bütschi, G., Flodin, B. (2004). A first look for parameters of public relations in Europe. Journal of public relations research, 16 (1), 35-63.

- Savič, I. (2016). Mediatization of companies as a factor of their communication power and the new role of public relations. Public relations review: doi:10.1016/j.pubrev.2016.03.017.

- Srirameh, K., Verčič, D. (2012). Introduction. In: Sriramesh, K., Verčič, D. (Eds.), Culture and public relations: Links and Implications (pp. 1-7). New York and London: Routledge.

- Stewart, T. S. (1998). Intellectual capital: The new wealth of organizations. London: Nicholas Brealey Publishing.

- Tkalac Verčič, A., Verčič, D., Laco, K. (2008). Comparing advertising and editorials: An experimental study in TV and print. Public relations review, 34 (4), 380-386.

- Tkalac Verčič, A., Verčič, D., Sriramesh, K. (2012). Internal communication: Definition, parameters, and the future. Public relations review, 38 (2), 223-230.

- Verčič, D., Grunig, J. E. (2000). The origins of public relations theory in economics and strategic management. In: Moss, D., Verčič, D., Warnaby, G. (Eds.), Perspectives on public relations research (pp. 9-58). London: Routledge.

- Verčič, D., Ruler, B. van, Bütschi, G., Flodin, B. (2001). On the definition of public relations: a European view. Public relations review, 27 (4), 373-387.

- Verčič, D., Tkalac Verčič, A. (2015). From reflexive to reflective mediatisation. Public relations review, 41 (4), $142-152$.

- Verčič, D., Verhoeven, P., Zerfass, A. (2014) Key issues of public relations of Europe: Findings from the European Communication Monitor 2007-2014. Revista Internationales de Relaciones Públicas, 6 (8), 5-26.

- Vidaver-Cohen, D. (2007). Reputation beyond the rankings: A conceptual framework for business school research. Corporate Reputation Review, 10 (4), 278-304.

- Welch, H., Jackson, P. R. (2007). Rethinking internal communication: A stakeholder approach. Corporate communication, $12(2), 177-198$

- Zerfass, A., Tench, R., Verčič, D., Verhoeven, P., Moreno, A. (2014). European Communication Monitor 2014. Excellence in strategic communication - Key issues, leadership, gender and mobile media. Results of a survey in 42 countries. Brussels. Belgium: EACD/EUPRERA, Helios Media.

- Zerfass, A., Verčič, D., Wiesenberg, M. (2016a). Managing CEO communication and positioning. Journal of communication management, 20 (1), 37-55.

- Zerfass, A., Verčič, D., Wiesenberg, M. (2016). The dawn of a new golden age for media relations? How PR professionals interact with the mass media and use new collaboration practices. Public relations review: doi:10.1016/j.pubrev.2016.03.005.

- Zerfass, A., Verčič, D., Verhoeven, P., Moreno, A., Tench, R., (2015). European Communication Monitor 2015. Creating communication value through listening, messaging and measurement. Results of a survey in 41 countries. Brussels. Belgium: EACD/EUPRERA, Helios Media. 


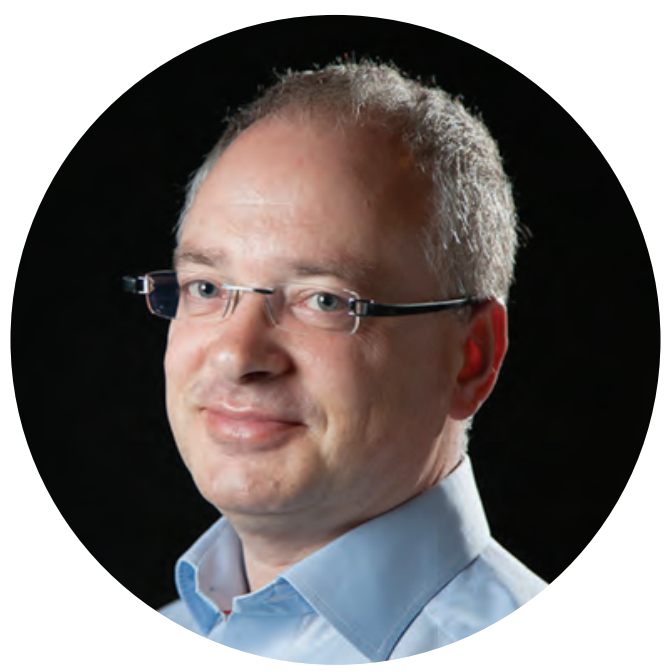

\section{Dejan Verčič}

Dejan Verčič is a Professor and Head of Center for Marketing and Public Relations at the University of Ljubljana, Slovenia. He holds a PhD from the London School of Economics and Political Science (LSE) and he was a Fulbright scholar at San Diego State University, USA. He is past president of EUPRERA. He received special awards by the Public Relations Society of Slovenia, the Alan Campbell-Johnson Medal by the UK Chartered Institute of Public Relations (of which he is a Fellow) and he was elected an Honorary Member of the Croatian Public Relations Association, and into the Arthur Page Society (USA). 